\title{
Distributed Generation: Technologies and Power Quality Issues
}

\author{
${ }^{1}$ S. S. Dhamse, ${ }^{2}$ Dr. W. Z. Gandhare \\ ${ }^{1}$ Research Scholar, Government College of Engineering, Aurangabad (India). \\ ${ }^{2}$ Principal, Government College of Engineering, Amravati (India).
}

\begin{abstract}
With the energy problems increasing seriousness, distributed generation is growing day by day. The distributed generation has wide range of applications for the merits of small investment, reliable and clean power supply, flexible generation manner, environment protection etc. DG can be used in an isolated way, supplying the consumer's local demand, or integrated into the grid supplying energy to the electrical power system. Distributed generation can run on renewable energy resources, fossil fuels or waste heat. DG can meet all or part of consumer's meet power needs. If connected to a distribution or transmission system, power can be sold to the utility. In this paper, an attempt is made to discuss different types of distribution generation and sources of distributed generation such as fuel cell, solar energy, wind energy, micro turbine. In this paper, different issues of power quality are also discussed.
\end{abstract}

Key words: Distributed Generation, Micro turbines, Photovoltaic, Power Quality, Reciprocating Diesel Engines

\section{Introduction}

Distributed Generation generally refers to small-scale electric power generators that produce electricity at a site close to customers or that are tied to an electric distribution system [1].

IEEE defines Distribution Generations as the generation of electricity by facilities sufficiently smaller than central plants, usually $10 \mathrm{MW}$ or less, so as to allow interconnection at nearly any point in the power system.

Electric Power Research Institute (EPRI) defines Distributed Generation as generation from a few kilowatts up to $50 \mathrm{MW}$.

International Energy Agency (IEA) defines Distributed Generation as power generation equipment and system used generally at distribution levels and where the power is mainly used locally on site.

The International Council on Large Electricity Systems defines Distributed Generation as generation that is not centrally planned, centrally dispatched at present, usually connected to the distribution network, and smaller than 50-100 MW.

Distribution generators includes, but are not limited to synchronous generators, reciprocating engines, micro turbines, combustion gas turbines, fuel cells, solar photovoltaic and wind turbines. These generators are distributed throughout the power system closer to the loads. The DG penetration in the grid poses new challenges and problems to the network operators as these can have a significant impact on the system and equipment operations in terms of steady state operation, dynamic operation, reliability, power quality, stability and safety for both customers and electricity suppliers.

\section{Types Of Dg}

Generally, classification of DG is based on three aspects:

1. According to the type of technology, DG can be divided into wind power, solar photovoltaic, small hydropower, fuel cells, micro turbines etc.

2. Based on the use of primary energy, DG can be divided into renewable energy and non-renewable energy.

3. In accordance with the interface to power system, DG can be divided into associated (electromechanical) and through the inverted connected system [3].

\section{Dg Technologies [2][3]}

\subsection{Reciprocating Diesel or Natural Gas Engines}

Reciprocating engines, developed more than 100 years ago, were the first among DG technologies. Both Otto (spark ignition) and Diesel cycle (compression ignition) engines have gained widespread acceptance in almost every sector of the economy. They are used on many scales, with applications ranging from fractional horsepower units that power small tools to enormous $60 \mathrm{MW}$ base load electric power plants. Smaller engines are primarily designed for transportation and can usually be converted to power generation with little modification. Larger engines are most frequently designed for power generation, mechanical drive, or marine propulsion.

Reciprocating engines can be fueled by diesel or natural gas, with varying emission outputs. Almost all engines used for power generation are four-stroke and operate in four cycles (intake, compression, combustion, 
Distributed Generation: Technologies And Power Quality Issues

and exhaust). The process begins with fuel and air being mixed. In turbocharged applications, the air is compressed before mixing with fuel. The fuel/air mixture is introduced into the combustion cylinder and ignited with a spark. For diesel units, the air and fuel are introduced separately with fuel being injected after the air is compressed. Reciprocating engines are currently available from many manufacturers in all size ranges. They are typically used for either continuous power or backup emergency power. Cogeneration configurations are available with heat recovery from the gaseous exhaust.

\subsection{Micro turbines}

Micro turbines are an emerging class of small-scale distributed power generation in the $30-400 \mathrm{~kW}$ size range. The basic technology used in micro turbines is derived from aircraft auxiliary power systems, diesel engine turbochargers, and automotive designs. A number of companies are currently field-testing demonstration units, and several commercial units are available for purchase.

Micro turbines consist of a compressor, combustor, turbine, and generator. The compressors and turbines are typically radial-flow designs, and resemble automotive engine turbochargers. Most designs are single-shaft and use a high-speed permanent magnet generator producing variable voltage, variable frequency alternating current (AC) power. Most micro turbine units are designed for continuous-duty operation and are recuperated to obtain higher electric efficiencies.

\subsection{Combustion Gas Turbines}

Combustion turbines range in size from simple cycle units starting at about $1 \mathrm{MW}$ to several hundred MW when configured as a combined cycle power plant. Units from 1-15 MW are generally referred to as industrial turbines (or sometimes as mini turbines), which differentiates them both from larger utility grade turbines and smaller micro turbines. Units smaller than $1 \mathrm{MW}$ exist, but few have been installed in the U.S. Industrial turbines are currently available from numerous manufacturers. Historically, they were developed as aero derivatives, spawned from engines used for jet propulsion. Some, however, are designed specifically for stationary power generation or compression applications in the oil and gas industries. Multiple stages are typical and along with axial blading differentiate these turbines from the smaller micro turbines described above.

Combustion turbines have relatively low installation costs, low emissions, and infrequent maintenance requirements. However, their low electric efficiency has limited turbines to primarily peaking unit and combined heat and power (CHP) applications. Cogeneration DG installations are particularly advantageous when a continuous supply of steam or hot water is desired.

\subsection{Fuel Cells}

Although the first fuel cell was developed in 1839 by Sir William Grove, it was not put to practical use until the 1960's when NASA installed this technology to generate electricity on Gemini and Apollo spacecraft. There are many types of fuel cells currently under development in the $5-1000+\mathrm{kW}$ size range, including phosphoric acid, proton exchange membrane, molten carbonate, solid oxide, alkaline, and direct methanol. One company, International Fuel Cells/ONSI, currently manufacturers a $200 \mathrm{~kW}$ phosphoric acid fuel cell for use in commercial and industrial applications. A number of companies are close to commercializing proton exchange membrane fuel cells, with marketplace introductions expected soon.

Although the numerous types of fuel cells differ in their electrolytic material, they all use the same basic principle. A fuel cell consists of two electrodes separated by an electrolyte. Hydrogen fuel is fed into the anode of the fuel cell. Oxygen (or air) enters the fuel cell through the cathode. With the aid of a catalyst, the hydrogen atom splits into a proton $(\mathrm{H}+)$ and an electron. The proton passes through the electrolyte to the cathode and the electrons travel in an external circuit. As the electrons flow through an external circuit connected as a load they create a DC current. At the cathode, protons combine with hydrogen and oxygen, producing water and heat. Fuel cells have very low levels of $\mathrm{NO}_{\mathrm{x}}$ and $\mathrm{CO}$ emissions because the power conversion is an electrochemical process. The part of a fuel cell that contains the electrodes and electrolytic material is called the "stack," and is a major contributor to the total cost of the total system. Stack replacement is very costly but becomes necessary when efficiency degrades as stack operating hours accumulate.

Fuel cells require hydrogen for operation. However, it is generally impractical to use hydrogen directly as a fuel source; instead, it must be extracted from hydrogen-rich sources such as gasoline, propane, or natural gas. Cost effective, efficient fuel reformers that can convert various fuels to hydrogen are necessary to allow fuel cells increased flexibility and commercial feasibility [4].

\subsection{Photovoltaic (PV)}

Edmund Becquerel, French physicist, discovered in 1839 that certain materials produced small electric currents when exposed to light. His early experiments were about 1 to 2 percent efficient in converting light to electricity and precipitated research into these photovoltaic effects. In the 1940's material science evolved and the Czochralski process of creating very pure crystalline silicon was developed. This process was used in 1954 
by Bell Labs to develop a silicon photovoltaic cell that increased the light to electricity conversion efficiency to 4 percent. Photovoltaic systems are commonly known as solar panels. Photovoltaic (PV) solar panels are made up of discrete cells connected together that convert light radiation into electricity. The PV cells produce directcurrent (DC) electricity, which must then be inverted for use in an AC system. Current units have efficiencies of $24 \%$ in the lab and $10 \%$ in actual use, below the $30 \%$ maximum theoretical efficiency that can be attained by a PV cell.

Insolation is a term used to describe available solar energy that can be converted to electricity. The factors that affect insolation are the intensity of the light and the operating temperature of the PV cells. Light intensity is dependent on the local latitude and climate and generally increases as the site gets closer to the equator. Photovoltaic systems produce no emissions, are reliable, and require minimal maintenance to operate. They are currently available from a number of manufacturers for both residential and commercial applications, and manufacturers continue to reduce installed costs and increase efficiency. Applications for remote power are quite common.

\subsection{Wind Turbines}

Windmills have been used for many years to harness wind energy for mechanical work like pumping water. Before the Rural Electrification Act in the 1920's provided funds to extend electric power to outlying areas, farms were using windmills to produce electricity with electric generators. In the U.S. alone, eight million mechanical windmills have been installed.

Wind energy became a significant topic in the 1970's during the energy crisis in the U.S. and the resulting search for potential renewable energy sources. Wind turbines, basically windmills dedicated to producing electricity, were considered the most economically viable choice within the renewable energy portfolio. Today, attention has remained focused on this technology as an environmentally sound and convenient alternative. Wind turbines produce electricity without requiring additional investments in infrastructure such as new transmission lines, and are thus commonly employed for remote power applications. They are currently available from many manufacturers and improvements in installed cost and efficiency continue. Wind turbines are packaged systems that include the rotor, generator, turbine blades, and drive or coupling device. As wind blows through the blades, the air exerts aerodynamic forces that cause the blades to turn the rotor. As the rotor turns, its speed is altered to match the operating speed of the generator. Most systems have a gearbox and generator in a single unit behind the turbine blades. As with PV systems, the output of the generator is processed by an inverter that changes the electricity from DC to AC so that the electricity can be used.The comparison of DG sources is shown in Table 1.

Table 1

Comparison Of Dg Technologies

\begin{tabular}{|l|c|c|c|c|c|c|c|}
\hline $\begin{array}{l}\text { Technique } \\
\text { Type }\end{array}$ & $\begin{array}{c}\text { Recip } \\
\text { Engine: } \\
\text { Diesel }\end{array}$ & $\begin{array}{c}\text { Recip } \\
\text { Engine: } \\
\text { NG }\end{array}$ & Microturbine & $\begin{array}{c}\text { Combustion } \\
\text { Gas } \\
\text { Turbine }\end{array}$ & $\begin{array}{c}\text { Fuel } \\
\text { Cell }\end{array}$ & Solar & $\begin{array}{c}\text { Wind } \\
\text { Power }\end{array}$ \\
\hline Size & $\begin{array}{l}30 \mathrm{~kW}- \\
6+\mathrm{MW}\end{array}$ & $\begin{array}{l}30 \mathrm{~kW}- \\
6+\mathrm{MW}\end{array}$ & $30-400 \mathrm{~kW}$ & $\begin{array}{c}0.5- \\
30+\mathrm{MW}\end{array}$ & $\begin{array}{c}100- \\
3000 \mathrm{~kW}\end{array}$ & $\begin{array}{c}1 \mathrm{~kW}- \\
1 \mathrm{MW}\end{array}$ & $\begin{array}{c}600 \mathrm{~kW}- \\
2500 \mathrm{~kW}\end{array}$ \\
\hline $\begin{array}{l}\text { Installed } \\
\text { Cost } \\
\text { (\$/kW)* }\end{array}$ & $600-$ & $700-$ & $1,200-1,700$ & $400-900$ & $4,000-$ & 6600 & $250-312.5$ \\
\hline $\begin{array}{l}\text { Elec. } \\
\text { Efficiency } \\
\text { (LHV) }\end{array}$ & $30-43 \%$ & $30-42 \%$ & $14-30 \%$ & $21-40 \%$ & $36-50 \%$ & $6-19 \%$ & $2-34 \%$ \\
\hline $\begin{array}{l}\text { Overall } \\
\text { Efficiency** }\end{array}$ & $80-85 \%$ & $80-85 \%$ & $80-85 \%$ & $80-90 \%$ & $80-85 \%$ & $45-60 \%$ & $40-78 \%$ \\
\hline $\begin{array}{l}\text { Total } \\
\text { Maintenance } \\
\text { Costs*** } \\
\text { (\$/kWh) }\end{array}$ & $0.005-$ & $0.007-$ & $0.008-0.015$ & $0.004-0.010$ & $0.0019-$ & $0.001-$ & $0.0125-$ \\
\hline
\end{tabular}


Distributed Generation: Technologies And Power Quality Issues

\begin{tabular}{|c|c|c|c|c|c|c|c|}
\hline $\begin{array}{l}\text { Site Area } \\
(\mathbf{s q f t} / \mathbf{k W})\end{array}$ & $.22-.31$ & $.28-.37$ & $.15-.35$ & $.02-.61$ & .9 & $\begin{array}{l}\text { Uncertain, } \\
\text { depending } \\
\text { on the } \\
\text { size of the } \\
\text { power }\end{array}$ & $\begin{array}{l}\text { Uncertain, } \\
\text { depending } \\
\text { on the } \\
\text { size of the } \\
\text { power }\end{array}$ \\
\hline $\begin{array}{l}\text { Emissions } \\
\text { (gm / bhp-hr } \\
\text { unless } \\
\text { otherwise } \\
\text { noted) }\end{array}$ & $\begin{array}{l}\mathrm{NO}_{\mathrm{x}}: 7- \\
9 \\
\mathrm{CO}: \\
0.3-0.7\end{array}$ & $\begin{array}{l}\mathrm{NO}_{\mathrm{x}}: \\
0.7-13 \\
\text { CO: } 1-2\end{array}$ & $\begin{array}{l}\mathrm{NO}_{\mathrm{x}}: 9- \\
50 \mathrm{ppm} \\
\text { CO: 9-50ppm }\end{array}$ & $\begin{array}{c}\mathrm{NO}_{\mathrm{x}}:<9- \\
50 \mathrm{ppm} \\
\\
\mathrm{CO}:<15- \\
50 \mathrm{ppm}\end{array}$ & $\begin{array}{l}\mathrm{NO}_{\mathrm{x}}: \\
<0.02 \\
\mathrm{CO}: \\
<0.01\end{array}$ & Nothing & Nothing \\
\hline $\begin{array}{l}\text { Reliability } \\
\text { level }\end{array}$ & Higher & higher & $\begin{array}{l}\text { no operation } \\
\text { experiment }\end{array}$ & higher & high & not high & not high \\
\hline
\end{tabular}

* Installation costs in accordance with the size of the installation power, the location of the installation, networking fee and other fee changes

** assuming CHP

*** Fuel costs vary significantly by region, and the numbers in this row assume minimum fuel cost.

\section{Power Quality Issues [5]}

There can be completely different definitions for power quality, depending on one's frame of reference. The utility may define power quality as reliability and show statistics demonstrating that the system is $99.98 \%$ reliable. The manufacturer of load equipment may define power quality as those characteristics of power supply that enable the equipment to work properly. These can be very different for different equipment and different manufacturers. However, power quality is ultimately a customer driven issue and the customer's point of reference takes precedence.

A perfect power supply would be one that is always available, always within voltage and frequency tolerances, and has a pure noise-free sinusoidal wave shape. Just how much deviation from perfection can be tolerated depends on the user's application, the type of equipment installed and his view of his requirements. Consequently, ensuring good power quality requires good initial design, effective correction equipment, cooperation with the supplier, frequent monitoring and good maintenance. In other words, it requires a holistic approach and a good understanding of the principles and practice of power quality improvement. Especially, for wind turbine generator systems, there are some international standard available that characterizing the power quality of a grid connected wind turbine.

Major issues related to power quality in distributed generation are-

\subsection{System Frequency}

The system frequency deviates from rated value due to imbalance between demand and supply of electricity. These should be kept within very narrow margins, as the well functioning of many industrial and household applications depends on it. The transmission grid operator is appointed to take care of the system frequency as well as the other services with a public good character that need to be provided.

Other reason to affect the supply frequency is the installation and connection of DG units. These units will free ride on the efforts of the transmission grid operator or the regulatory body to maintain system frequency. They will probably have to increase their efforts and having an impact on plants efficiency and emissions. Therefore, the connection of an increasing number of DG units should be carefully evaluated and planned upfront.

\subsection{Voltage Level}

The large scale introduction of decentralised power generating units may lead to instability of the voltage profile. It is due to the bidirectional power flows and the complicated reactive power equilibrium arising when efficient control is introduced, the voltage throughout the grid may fluctuate. An islanding situation may occur in which a local generator keeps a part of disconnected grid energised leading to dangerous situations for the repair personnel coming in. The impact on the local voltage level of DG connected to the distribution grid can be significant. The IEA mentions voltage control as an issue when DG is connected to the distribution grid. This does not need to be problem when the grid operator faces difficulties with low voltages, as in that case The DG unit can be contribute to the voltage support. But in other situations it can result in additional problems. 


\subsection{Reactive Power}

DG units with a power electronic interface are sometimes capable to deliver reactive power. However, small and medium sized DG units often use asynchronous generators that are not capable of providing reactive power. Several options are available to solve this problem. On other hand, DG units with a power electronic interface are sometimes capable to derive reactive power.

\subsection{Power Conditioning}

There are some DG technologies like photovoltaic, fuel cells which produce direct current. Thus, these units must be connected to the grid via a DC-AC interface, which may contribute to higher harmonics. Special technologies are also required for systems producing a variable frequency AC voltage. Such power electronic interfaces have the disadvantage that they have virtually no inertia, which can be regarded as a small energy buffer capable to match fast changes in the power balance. Similar problems arise with variable wind speed machines.

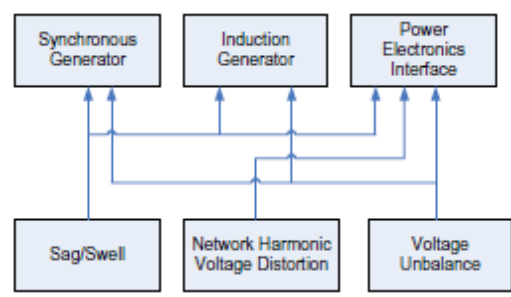

Fig.1. Impact of PQ issues on DG systems

The impact of power quality issues on distributed generation systems is shown in fig. 1 .

\section{Conclusions}

In this paper, different types and sources of distributed generation are discussed. Fuel cell, solar energy, wind energy, micro turbine are the main sources of the distributed generation. It is clear that most sources available for DG are renewable. The use of DG sources depends on several factors which includes plant location and system specification.

In this paper, different issues of power quality are also discussed. It is concluded that when interconnecting distributed resources to the power system, these issues must be considered which could affect power quality and safety.

\section{References}

[1] R. C. Dugan, M. F. McGranaghan, S. Santoso, H.W. Beaty, "Electrical Power System Quality", McGraw Hill.

[2] Hu Xue-hao, "Distributed Generation Technology and its Problems Incorporating into Power Network", Electrotechnical Journal, vol. 10 , pp. 1-5, 2004.

[3] A. D. Hansen, E. C. Lopez, J. Persson, H. Knudsen, J. N. Nielsen, "Wind Power in Power Systems", John Wiley \& Sons.

[4] A. F. Zobaa, C. Cecati, "A Comprehensive Review on Distributed Power Generation", SPEEDAM 2006.

[5] J. Driesen, R. Belmans, "Distributed Generation: Challenges and Possible Solutions", IEEE2006. 